\title{
Reverse Engineering Approach for the Design of Gear-box for a Hand-guided Vibratory Roller Soil-Compactor
}

\author{
*S. A. B. Fiyebo' ${ }^{1}$, Osagie Ibhadode ${ }^{1}$, M. O. Fabiyi ${ }^{1}$, Adebayo Adekunle ${ }^{1}$ \\ Research Officer ${ }^{1}$ \\ Nigerian Building and Road Research Institute (NBRRI) \\ [Federal Ministry of Science and Technology] \\ Abuja, \\ Nigeria
}

\begin{abstract}
Soil compaction is one of the most critical components in the construction of roads, airfields, embankments and foundations. For a developing country like Nigeria, the equipment needed to compact soil for the above-mentioned purposes especially in the rural areas needs to be readily available. However, this is usually not the case as most of the available equipment like Roller compactors are imported. A cheaper and faster way to make them available is by reproducing the existing ones through 'Reverse Engineering'. Reverse Engineering (RE) can be defined as the process of discovering the technological principles of a device, object or system through analysis of its structure, function and operation usually for the purpose of reproducing it or for a more competitive procurement. In this project, the Reverse Engineering design (mechanical) of a parallel shaft gearbox for use in a hand roller compactor was carried-out. Its entire functionality was outlined and the engine capacity to be coupled to the gear box in order to provide the required energy for an acceptable soil compaction was determined. The energy required according to Standard Compaction Test AS 1289 - E1.1 ranges from $595 \mathrm{KJ} / \mathrm{m}^{3}$ to $2072 \mathrm{KJ} / \mathrm{m}^{3}$ according to the Modified Compaction Test AS 1289 - E2.1. Therefore, the energy required for various levels of compaction, ranges between these two values. Four different soil types were considered and the energy required for different 'Compacted lift thicknesses' using the parameters of the hand roller compactor were found to fall within the above values $\left(595-2072 \mathrm{KJ} / \mathrm{m}^{3}\right)$, thus, justifying the viability of this design procedure.
\end{abstract}

Key Words: Base pitch, Circular pitch, Pitch circle diameter, Compacted lift thickness, Specific energy.

\section{INTRODUCTION}

Reverse Engineering (RE) used to be a nefarious term. It formerly meant copying a product or the outright stealing of ideas from competitors. In current usage however, reverse engineering (RE) has taken on a more positive character and now simply refers to the process of creating a descriptive data set from a physical object [1]. Over the years, the meaning of reverse engineering has evolved based on the different techniques and tools used, and also the intent of carrying it out. Below are some of its definitions.

Reverse engineering is taking apart an object to see how it works in order to duplicate or enhance the object [2]. It is the process of duplicating an item functionally and dimensionally by physically examining and measuring existing parts to develop the technical data (physical and material characteristics) required for competitive procurement [3]. Reverse engineering (RE) can be defined as the process of obtaining a geometric Computer-Aided Design (CAD) model from three-dimensional (3-D) points acquired by scanning/digitizing existing parts/products; which is a concept of producing a part based on an original or physical model without the use of an engineering drawing [4]. Reverse Engineering is the process of retrieving new geometry from a manufactured part by digitizing and modifying an existing CAD model [5]. Reverse Engineering was later referred to as 'Computer-Aided Reverse Engineering (CARE)', and can be seen as a more advanced technique for data capturing of the original part. Earlier advanced techniques had involved the use of a Coordinate Measuring Machine (CMM). From these various views, reverse engineering can be generally defined as 'the process of taking a finished product and reconstructing design data in a format from which new parts or molds can be produced.' [6]. Purposes for carrying out Reverse Engineering may be that the original manufacturer of a product no longer produces the product, e.g., the original product has become obsolete, or that the original product design documentation has been lost or never existed. Also, RE maybe carried-out for the purpose of exploring 
new avenues to improve product performance and features, amongst others [7], [8], [9], [10], [11], [12], [13]. The aim of this study is to carry-out the Reverse Engineering design of a damaged/malfunctional gearbox for a hand roller compactor, for the purpose of determining the operational principle and the power of the engine to be coupled with a similar type that will be produced as a proposed replacement. Also, it should be note that, 'Soil Compaction' is basically a three-stage process of mechanically densifying a soil—which essentially comprises of three consecutive stages i.e. Compression stage [during which large-sized air-filled pore spaces are crushed to become small-sized water-filled pores], Compaction stage [during which soil aggregates are destroyed \& aeration pores are collapsed], and Consolidation stage [during which there is an increase in number \& strength of internal bonds].

\section{Nomenclature}

$P_{b}$ or $\mathrm{M}=\quad$ Base pitch of gear, mm

$\mathrm{m} \quad=\quad$ Module of gear, $\mathrm{mm}$

$P_{c}=\quad$ Calculated circular pitch of gear, $\mathrm{mm}$

$P_{c}{ }^{\prime}=$ Rough measurement of circular pitch, $\mathrm{mm}$

$\phi \quad=\quad$ Chosen pressure angle; $20^{\circ}, 25^{\circ}$ or $14.5^{\circ}$

$\phi^{\prime}=$ First calculated value of pressure angle

$d \quad=\quad$ Pitch circle diameter, $\mathrm{mm}$

$t \quad=\quad$ Tooth thickness, $\mathrm{mm}$

$\mathrm{z}=\quad$ Number of teeth on gears

$n_{s} \quad=\quad$ Number of teeth of sprocket outside gearbox

$n_{R} \quad=\quad$ Number of teeth of sprocket attached to Roller

$v \quad=\quad$ Linear translational speed of Roller, $\mathrm{m} / \mathrm{s}$

$\omega_{R}=$ Angular speed of Roller, $\mathrm{rad} / \mathrm{s}$

$\omega_{g} \quad=\quad$ Angular speed of gears, $\mathrm{rad} / \mathrm{s}$

$\omega_{s}=\quad$ Angular speed of sprocket outside gearbox, $\mathrm{rad} / \mathrm{s}$

$r \quad=\quad$ Radius of Roller

$\gamma \quad=\quad$ Gearbox ratio

$T=$ Transmitted torque by clutch, $\mathrm{Nm}$

$F \quad=\quad$ Operating force of clutch, $\mathrm{N}$

$f \quad=\quad$ Coefficient of friction between clutch material and gear

$\alpha=\quad$ Conical angle of clutch

$D \quad=\quad$ Larger conical clutch diameter, $\mathrm{mm}$

$d=\quad$ Smaller conical clutch diameter, $\mathrm{mm}$

$P_{a}=$ Maximum pressure on clutch, $\mathrm{N} / \mathrm{m}^{2}$

$P \quad=\quad$ Power of engine, Watts

$\omega_{\mathrm{e}} \quad=\quad$ Angular speed of engine, $\mathrm{rad} / \mathrm{s}$

$E=$ Specific energy required for compaction, $\mathrm{KJ} / \mathrm{m}^{3}$

$R=\quad$ Rate of production during compaction operations, $\mathrm{m}^{3} / \mathrm{s}$

$W \quad=\quad$ Compacted width per pass, $\mathrm{m}$

$S=$ Compactor average speed, $\mathrm{m} / \mathrm{s}$

$L=$ Compacted lift thickness, $\mathrm{m}$

$\varepsilon \quad=\quad$ Efficiency factor during operations

$N \quad=\quad$ Number of required passes

$P_{c o}=\quad$ Useful power for compaction, $\mathrm{J} / \mathrm{s}$

\section{MATERIALS AND METHOD}

Figure 1 shows the flow chart of the processes involved in the reverse engineering of a malfunctional/damaged gearbox used for this work, which can be adopted for similar designs such as torque transmitting systems. Enumerated below are the steps taken for the reverse engineering design.

a) Preliminary operations

- Acquisition and Dissembling of the malfunctional/damaged Gearbox

b) Three-dimensional (3-D) Modelling of the proposed Gearbox

- Measurement/determination of dimensions of the malfunctional/damaged gearbox

- Creating 3-D models (Drawing) of the individual components of the proposed Gearbox using a CAD software such as AutoCAD

- Virtual assembly of components and Analytical determination of working/operational mechanism of Gearbox.

c) Determination of the Speed, Torque and Power of the Engine for the proposed Gearbox 
International Journal of Engineering Research And Advanced Technology, Vol.6 (10), October-2020

- Calculation of Speed of the Engine

- Performance of Force-Stress Analysis from its geometry to determine the Torque

- Calculation of Power of Engine

d) Determination of Gearbox Ratio

- Calculation of Gearbox Ratio

2.1 Acquisition and Dissembling of a Malfunctional/damaged Gearbox

A malfunctional/damaged gear box for a roller compactor was acquired from the local market for the purpose of reverse engineering. After which, work shop tools such as hammers, screw drivers, punches etc., were used to dissemble the gearbox into its individual components.

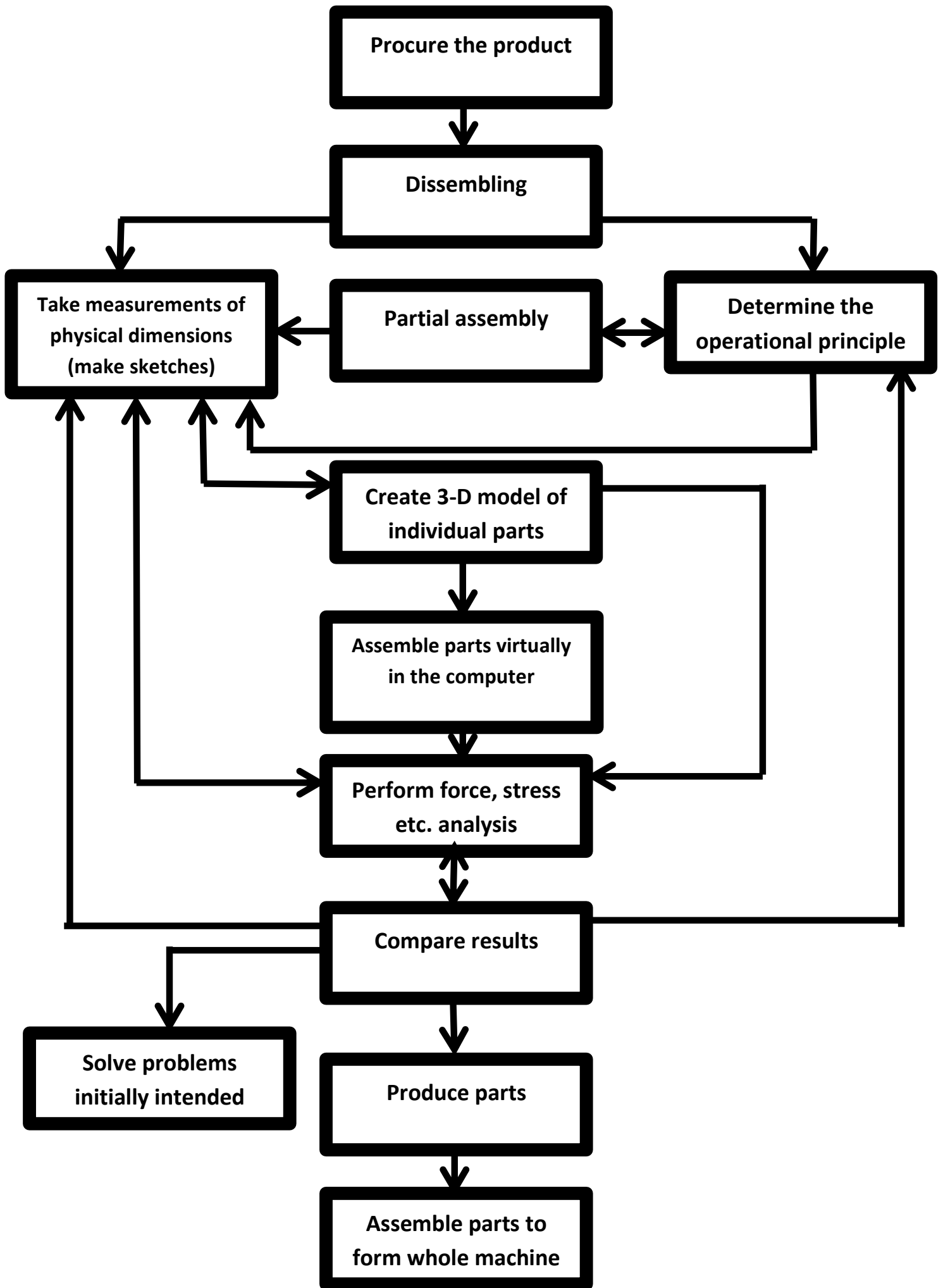

Figure 1: Flow chart showing procedures for the Reverse Engineering design \& fabrication of the proposed Gearbox for a Hand-guided Vibratory Roller Soil-Compactor.

(Source: Authors) 
Table 1: Gear Designation, Name, Number of teeth and Primary function

\begin{tabular}{|c|c|c|c|}
\hline $\begin{array}{c}\text { Gear } \\
\text { Designation }\end{array}$ & $\begin{array}{l}\text { Gear } \\
\text { Name }\end{array}$ & $\begin{array}{l}\text { Number of } \\
\text { teeth } \\
\text { ' } Z \text { ' }\end{array}$ & Primary function \\
\hline G1 & Forward input gear & 15 & Inputs power into the gear box \\
\hline G2 & Reverse gear & 18 & Reverses the direction of the input \\
\hline G3 & Forward reduction gear & 72 & $\begin{array}{l}\text { Reduces the speed of rotation in the forward } \\
\text { direction }\end{array}$ \\
\hline G4 & Revers reduction gear & 72 & $\begin{array}{l}\text { Reduces the speed of rotation in the reverse } \\
\text { direction }\end{array}$ \\
\hline G5 & $\begin{array}{l}\text { Input system transmission } \\
\text { gear }\end{array}$ & 21 & $\begin{array}{c}\text { Transmits motion from the forward and } \\
\text { reverses reduction gears to the idler gear } \\
\text { system }\end{array}$ \\
\hline G6 & Reduction idler gear & 64 & Further reduces speed of rotation \\
\hline G7 & Transmission idler gear & 18 & $\begin{array}{l}\text { Transmits motion to the higher speed output } \\
\text { gear }\end{array}$ \\
\hline G8 & Transmission idler gear & 14 & $\begin{array}{c}\text { Transmit motion to the lower speed output } \\
\text { gear }\end{array}$ \\
\hline G9 & Higher speed output gear & 41 & $\begin{array}{l}\text { Transmits motion to the sprocket outside the } \\
\text { gear box at the higher output speed }\end{array}$ \\
\hline G10 & Lower speed output gear & 45 & $\begin{array}{l}\text { Transmits motion to the sprocket outside the } \\
\text { gear box at the lower output speed }\end{array}$ \\
\hline
\end{tabular}

Source: Authors

\subsection{Measurement/determination of Dimensions of the Malfunctional/damaged Gearbox}

Traditional workshop tools such as Vernier caliper and measuring tape were used to take measurements of individual components of the dissembled damaged gearbox. The most important parameter that was measured was the 'Base Pitch' of the gears, from which other parameters of the gears were calculated. But first, it is necessary to identify all the gears used in the gear box. Table 1 shows the designated names given to the gears and their primary functions.

The determination of the 'Base Pitch (BP)' is the starting point and an important parameter of the gears in Reverse Engineering analysis. The Base Pitch (also known as the Normal or transverse Base Pitch for helical gears) is the distance on a normal base helix between corresponding involutes of adjacent teeth. Physically, this can be obtained by taking measurement over a suitable number of teeth. To achieve a better and a more accurate result, the following steps is adopted:

a) First, we need to determine the number of teeth over which measurements will be taken. The exact number of teeth to measure over will be determined by each individual gear such that the caliper does not contact the outer diameter. It is desirable to measure over the smallest numbers of teeth that will give a good "feel" and this is done from the pitch line as shown in the diagram below:

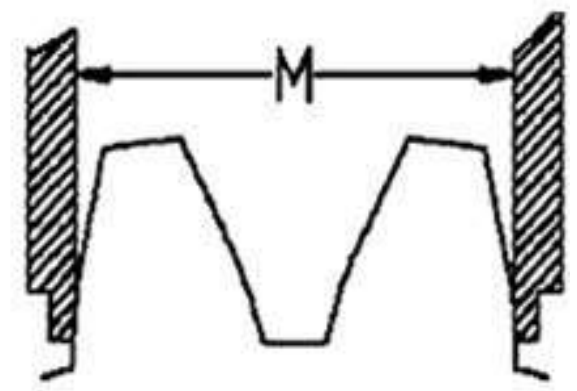

Figure 2: Base pitch measurement over two teeth Source: Authors

b) Take the measurements, For example, using 2 teeth as the starting point, we then measure over 3 teeth.

c) Subtract the 2- teeth reading from the 3-teeth reading. This is the base pitch. To be more accurate, we take three of these measurements over a different number of teeth and use the average as the base pitch. For example, we measure over $2 \&$ 3 teeth, $3 \& 4$ teeth and $4 \& 5$ teeth.

d) Calculate the average of these three subtractions which will be the desired base pitch [14]. 
The challenge of the measurements is mainly on the gears which are all simple spur gears. Only three measurements were taken on the gears; the outer diameter, the root diameter and the base pitch (which was the most important measurement that was taken). Although, some other measurements which can easily be taken may be necessary to aid faster 3D modelling. Other parameters of the gear can be calculated from these three measurements. The results for base pitch are shown in Table 2.

Having obtained the Base pitch, we then proceeded to determine other parameters, some of which were calculated while others were measured directly. Figure 3 below shows these other parameters. Thus, while 'Pitch circle diameter' and 'Tooth thickness' were obtained by calculation; the 'Outer diameter' [also called 'Addendum circle diameter'] and Face width were obtained by measurements. However, the 'Root diameter' [also called 'Dedendum circle diameter'] can be obtained by calculation, if measurement is difficult.

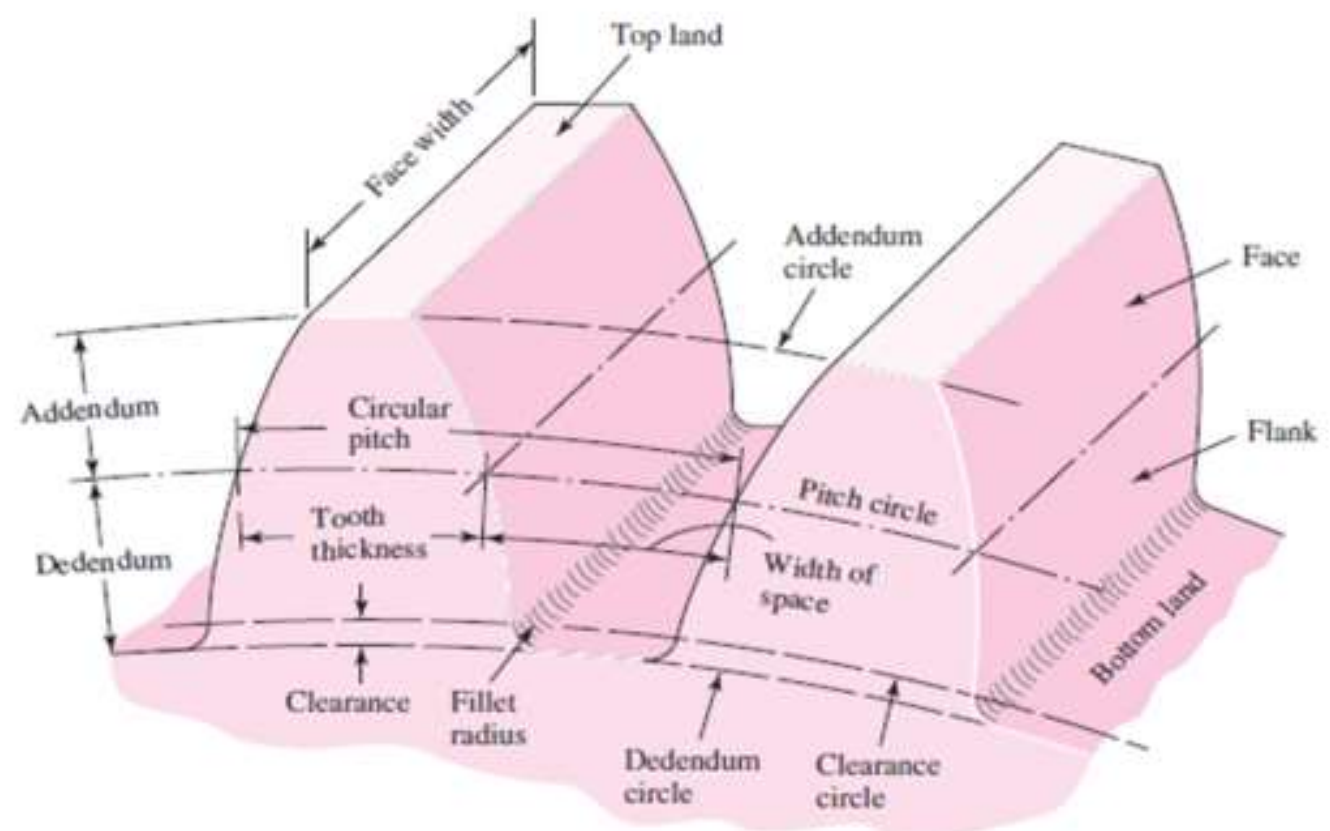

Figure 3: Gear Nomenclature

Source: [15]

After which, we developed the formulae and/or mathematically combined proven scientific relations to obtain the Pitch circle diameter and the Tooth thickness, as is summarily explained below. This is because, 'Pitch circle diameter' and 'Tooth thickness', together with some other required parameters [which will also be calculated], greatly affect/influence the conjugal action of the mating gears.

Now, we begin by noting that, the 'Pitch Circle' is a theoretical circle upon which gear calculations are usually based, whose diameter is the Pitch circle diameter which can be calculated from the relation:

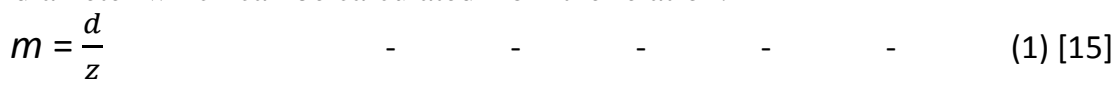

in (1), the only known parameter is ' $z$ ', while the other two, ' $m$ ' and ' $d$ ' are unknown; thus, it is not ideal for (1) to be used at this point. Consequently, another relation which can thus be used is:

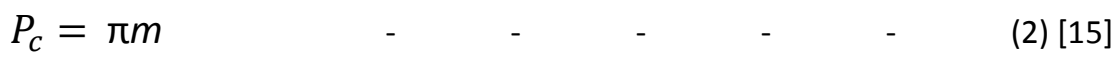

Where $P_{c}$ is called the 'Circular pitch' which is the distance measured on the pitch circle, from a point on one tooth to a corresponding point on an adjacent tooth. Although, this is also not known, but it can be calculated from the relations below:

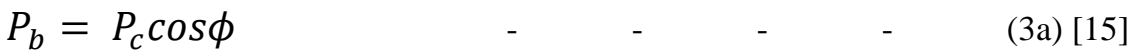

$$
\begin{aligned}
& P_{b}=P_{c}^{\prime} \cos \phi^{\prime} \quad \text { - } \quad \text { - } \quad \text { - } \quad \text { - } \quad \text { (3b) }
\end{aligned}
$$

$P_{b}$ is are the base pitch values which were determined and tabulated in Table 2. Also, $\phi$ is called the 'Pressure angle', which is the angle at a pitch point between the line of action (which is normal to the tooth surface) and the plane tangential to the pitch surface. Presently, Pressure angles of $20^{\circ}$ or $25^{\circ}$ are now adopted for Spur gear; however, $14.5^{\circ}$ was previously used. [15].

In this work, a rough measurement of the circular pitch of the gears used was first taken and ( $3 b$ ) used to calculate an initial value of the pressure angle. Then, any of $20^{\circ}, 25^{\circ}$ or $14.5^{\circ}$ was chosen (adopted) based on the closeness of calculated value to the three standard values i.e. of $20^{\circ}, 25^{\circ}$ or $14.5^{\circ}$. After which, the chosen/adopted value of Pressure angle was then used for the calculation of the Circular pitch, by substituting it into equation 3a. The results of these measurements and calculations are shown in Table 3 
Now combining (1), (2) and (3a) and solving for ' $d$ ' yields:

$$
d=\frac{N P_{b}}{\pi \cos \phi}
$$

The next parameter that was calculated was the Tooth thickness. This was determined from the relation:

$$
t=\frac{P_{c}}{2}
$$

Now, gears G1, G2, G3 and G4 are all systematically inter-mating in their action and therefore theoretically, they must have the same Circular pitch. However, the calculations performed above show otherwise; (though they are approximately very close, i.e. within the neighborhood of $7 \mathrm{~mm}$.) Therefore, it became necessary to take an average of all calculated values in order to obtain a better (more accurate) result.

Thus:

$$
P_{c}=\frac{7.13+7.61+7.02+7.02}{4}=7.2 \mathrm{~mm}
$$

Similarly, the average Tooth thickness will be given as:

$$
t=\frac{3.57+3.81+3.51+3.51}{4}=3.6 \mathrm{~mm}
$$

The same was done for gears G5, G6, G7 and G9; which also applied to G8 and G10; after which the results were tabulated as shown in Table 4

\subsection{Creating (Drawing) 3-D model of the individual components of the proposed Gearbox using a CAD software such as 'AutoCAD'}

The 3-D modelling of the gears and some other components/parts of the gearbox were done with AutoCAD software and are shown in Appendix 2 in their exploded views and sub-assemblies (Also shown are the clutches as individual components)

\subsection{Virtual assembly of components and Analytical determination of working principle of Gearbox.}

After the 3-D modelling of the individual components of the gearbox was completed, the assembly of the components was carried-out with the aid of the same AutoCAD software. This was immediately followed by the analytical determination of the working principle of the gearbox. This latter process, required direct physical examinations of the malfunctional/damaged gear box, and regular consultations of relevant literature previously published for better understanding.

\subsection{Calculation of Speed of the Engine}

Since one of the objectives of this study is to determine the power of the engine for the proposed gearbox, the Speed and Torque are of great importance, because the Power of the engine is a function of both its Speed and Torque. Thus, starting with the Linear Speed of the hand Roller Compactor, we established a mathematical relationship between it and the gears, as shown below.

Now, the maximum speed of the Hand Roller compactor is proposed to be $1.25 \mathrm{~km} / \mathrm{hr}$. This will also be the speed at the center of the roller as it rolls along the ground, doing its work. The Linear translational speed and Angular speed of the Hand Roller compactor are related by:

$$
v=\omega_{R} r
$$

A sprocket is attached to the roller [of the Hand Roller compactor] which has the same Angular speed as the roller. This sprocket is connected to the sprocket mounted on the shaft outside the gearbox. Both sprockets are connected via a chain and are related by the equation;

$$
\frac{\omega_{s}}{\omega_{R}}=\frac{n_{R}}{n_{s}}
$$

\subsection{Performance of Force-Stress Analysis from Gearbox geometry to determine the Torque}

The next required parameter that was determined was the transmitted Torque-which was later multiplied by the Angular speed to give the Power of the Engine. This transmitted torque was obtained by considering the conical clutch since it articulates with the inner surface of gears G3 and G4 (one at a time) which transmits torque and motion in the gear box from the engine. Now, the torque from the conical clutch is a function of its geometry. Figure 4 below illustrates this. 


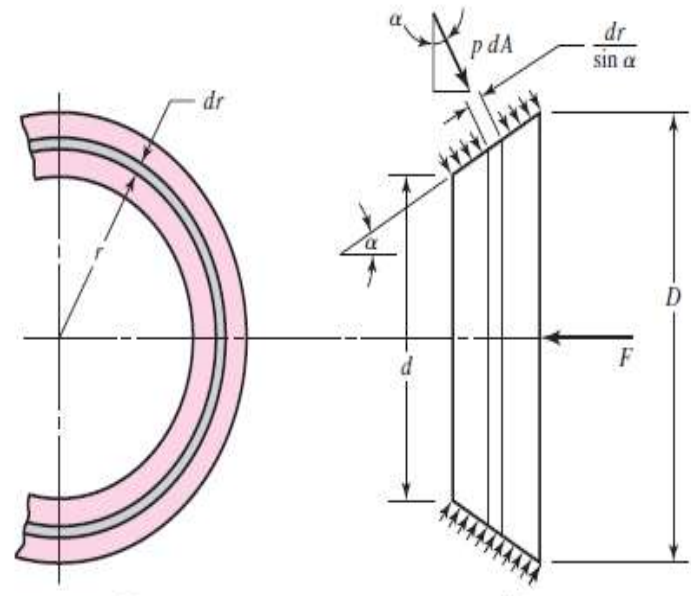

(a)

(b)

Figure4: Contact area of Conical Clutch [15]

When considering uniform wear of the conical clutch, the torque transmitted is given by;

$$
T=\frac{F f}{4 \sin \alpha}(D+d)
$$

and

$$
F=\frac{\pi P_{a} d}{2}(D-d)
$$

\subsection{Calculation of Power of Engine}

The Power of the engine was calculated as follows:

$$
\mathrm{P}=T \times \omega
$$

\subsection{Calculation of Gearbox Ratio}

The proposed gearbox has two forward output speeds and two reverse output speeds. The gearbox ratio was calculated based on the main output forward speed, as follows:

$$
\gamma=\frac{\text { driver gear speed }}{\text { driven gear speed }} \quad=\frac{\omega_{1}}{\omega_{9}} \quad-\quad \text { - } \quad \text { (11) }[20]
$$

\section{RESULTS AND DISCUSSION}

\subsection{Results of measured/calculated Gear parameters}

Reported and discussed below are the results and data (technical details) obtained through measurements, calculations and

\begin{tabular}{|c|c|c|c|c|c|c|c|c|c|}
\hline \multirow{2}{*}{$\begin{array}{c}\text { Gear } \\
\text { Designation }\end{array}$} & \multirow{2}{*}{$\begin{array}{c}\text { Mating } \\
\text { with Gear }\end{array}$} & \multicolumn{4}{|c|}{$\begin{array}{l}\text { Measurements over } \\
\text { Numbers of teeth } \\
\text { (mm) }\end{array}$} & \multicolumn{3}{|c|}{$\begin{array}{c}\text { Subtractions from } \\
\text { Numbers of teeth } \\
(\mathrm{mm})\end{array}$} & \multirow{2}{*}{$\begin{array}{l}\text { Average } \\
\text { value of } \\
\text { Base pitch } \\
\text { (mm) }\end{array}$} \\
\hline & & 2 & 3 & 4 & 5 & $3-2$ & $4-3$ & $5-4$ & \\
\hline G1 & G2 and G3 & 10.25 & 16.95 & - & - & 6.70 & & & 6.70 \\
\hline G2 & G1 and $\mathbf{G 4}$ & 10.25 & 17.15 & - & - & 6.90 & & & 6.90 \\
\hline G3 & G1 & 10.80 & 17.40 & 24.80 & 31.60 & 5.60 & 7.40 & 6.80 & 6.60 \\
\hline G4 & G2 & 10.80 & 17.40 & 24.80 & 31.60 & 5.60 & 7.40 & 6.80 & 6.60 \\
\hline G5 & G6 & 11.50 & 18.99 & - & - & 7.49 & & & 7.49 \\
\hline G6 & G5 & 12.50 & 19.80 & 27.50 & 34.85 & 7.30 & 7.70 & 7.35 & 7.45 \\
\hline G7 & G9 & 15.80 & 26.40 & - & - & 10.60 & & & 10.60 \\
\hline G8 & G10 & 15.80 & 26.40 & - & - & 10.60 & & & 10.60 \\
\hline G9 & G7 & 17.20 & 27.60 & 37.85 & - & 10.40 & 10.25 & & 10.33 \\
\hline G10 & G8 & 17.20 & 27.60 & 37.85 & - & 10.40 & 10.25 & & 10.33 \\
\hline
\end{tabular}
engineering analyses, as presented in Tables 2-4, illustrated in the Figures 6-8, Appendices 1-2, and the accompanying explanatory/analytical notes.

Table 2: Base pitch of Gears in the Gearbox 


\subsection{Working principle of the Gearbox}

Illustrated below in Figure 5 is the kinematic diagram of the gearbox, while Table 5 displays a summary of the main functions of the major sub-assemblies.

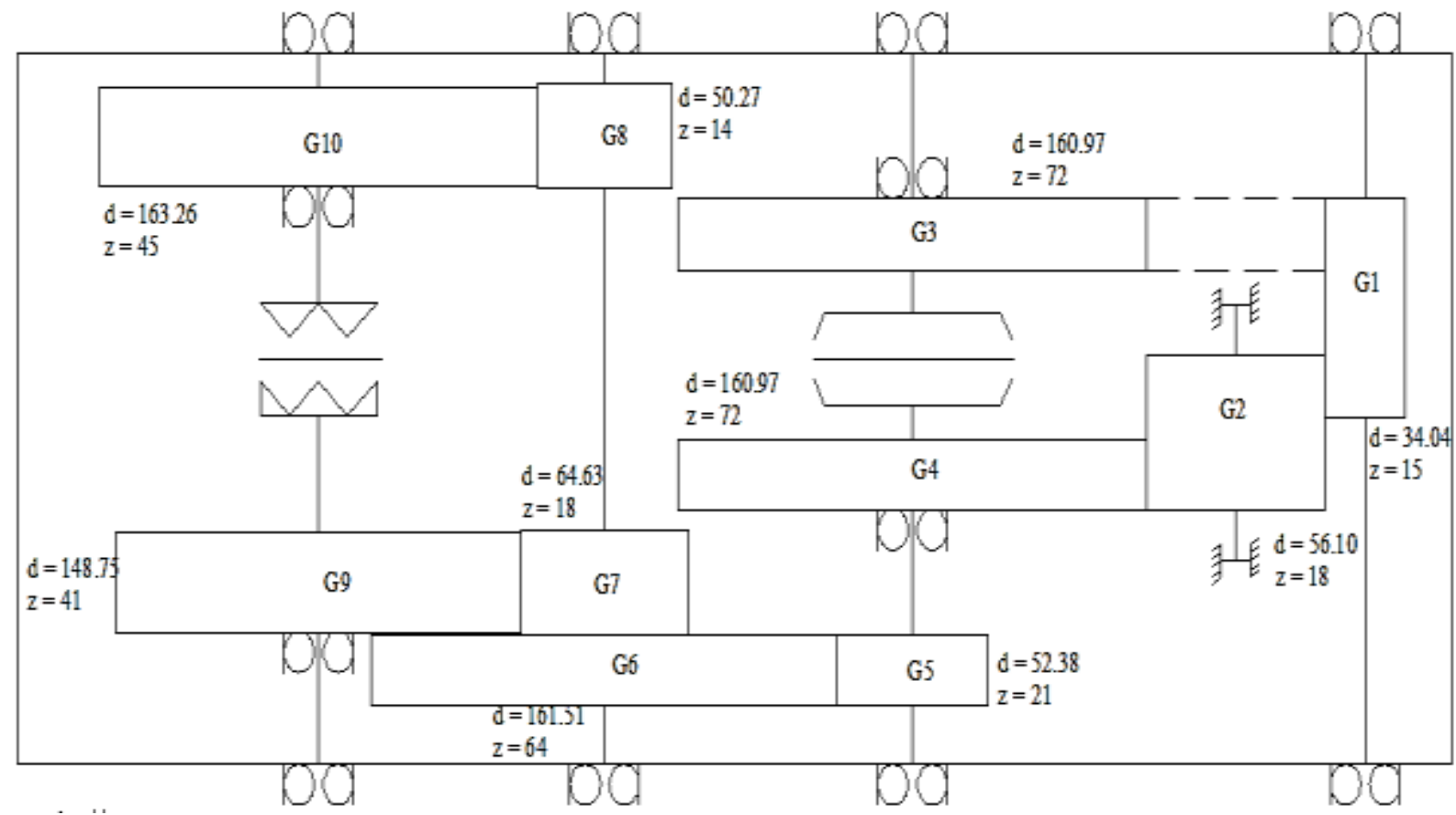

Figure 5: Kinematic diagram of Gear Box showing the pitch circle diameter, number of teeth and the designation of the gears

In the whole positioning of the gear box components - as could be seen in Figure 5, all the gears are mating accordingly. When the engine is turned on, gears G1, G2, G3 and G4 starts rotating accordingly while others are not yet rotating and so the roller compactor does not move. Gears G3 and G4 rotate independently and in opposite direction on bearings (A gap separates them from each other).

\begin{tabular}{|c|c|c|c|c|c|}
\hline $\begin{array}{c}\text { Gear } \\
\text { Designation }\end{array}$ & $\begin{array}{c}\text { Base Pitch } \\
P_{b} \\
(\mathrm{~mm})\end{array}$ & $\begin{array}{c}\text { Measured } \\
\text { Circular Pitch } \\
P_{c}^{\prime} \\
(\mathrm{mm})\end{array}$ & $\begin{array}{c}\text { Calculated } \\
\text { Pressure Angle } \\
\phi^{\prime} \\
\text { (degrees) }\end{array}$ & $\begin{array}{c}\text { Chosen } \\
\text { Pressure Angle } \\
\phi \\
\text { (degrees) }\end{array}$ & $\begin{array}{c}\text { Calculated } \\
\text { Circular Pitch } \\
P_{c} \\
(\mathrm{~mm})\end{array}$ \\
\hline G1 & 6.70 & 7.13 & 20.00 & 20.00 & 7.13 \\
\hline G2 & 6.90 & 7.13 & 14.59 & 14.50 & 7.34 \\
\hline G3 & 6.60 & 7.38 & 26.58 & 25.00 & 7.02 \\
\hline G4 & 6.60 & 7.38 & 26.58 & 25.00 & 7.02 \\
\hline G5 & 7.49 & 7.97 & 19.98 & 20.00 & 7.02 \\
\hline G6 & 7.45 & 7.93 & 20.04 & 20.00 & 7.93 \\
\hline G7 & 10.60 & 11.28 & 19.99 & 20.00 & 11.28 \\
\hline G8 & 10.60 & 11.28 & 19.99 & 20.00 & 11.28 \\
\hline G9 & 10.33 & 11.39 & 24.91 & 25.00 & 11.40 \\
\hline G10 & 10.33 & 11.39 & 24.91 & 25.00 & 11.40 \\
\hline
\end{tabular}

For the roller-compactor to move, the conical clutch has to engage either of gears G3 or G4. This is made possible by means of the systematic shaft assembly via a speed screw mechanism attached to the solid in the systematic shaft assembly and connected to levers on the roller compactor's handle via cables. As the lever is moved by the operator, the motion is transmitted to the speed screw mechanism through the cables which consequently causes it to turn by some revolutions, clockwise or anti-clockwise, pulling or pushing the solid shaft (which is freely inserted into the hollow shaft in the systematic shaft assembly) and loosely connected to the clutch by a key. The speed screw mechanism is indicated by a single screw in Figure 6 and-provides the axial force that holds the shaft in position. 
International Journal of Engineering Research And Advanced Technology, Vol.6 (10), October-2020

Table 4: Average values of Circular pitch, Tooth thickness and Pitch circle diameter of Gears in the Malfunctional/damaged Gearbox

\begin{tabular}{|c|c|c|c|c|}
\hline $\begin{array}{c}\text { Gear } \\
\text { Designation }\end{array}$ & Mating Gear(s) & $\begin{array}{c}\text { Calculated Average } \\
\text { Circular Pitch } \\
P_{c}\end{array}$ & $\begin{array}{c}\text { Tooth thickness } \\
\text { T } \\
(\mathbf{m m})\end{array}$ & $\begin{array}{c}\text { Pitch circle diameter } \\
\text { d } \\
(\mathbf{m m})\end{array}$ \\
\hline G1 & G2 and G3 & 7.2 & 3.6 & 34.04 \\
\hline G2 & G1 and G4 & 7.2 & 3.6 & 56.10 \\
\hline G3 & G2 & 7.2 & 3.6 & 160.97 \\
\hline G5 & G2 & 7.2 & 3.6 & 160.97 \\
\hline G6 & G5 & 7.95 & 3.98 & 52.38 \\
\hline G7 & G9 & 7.95 & 5.67 & 161.51 \\
\hline G8 & G10 & 11.38 & 5.67 & 64.63 \\
\hline G10 & G7 & 11.38 & 5.67 & 50.27 \\
\hline
\end{tabular}

Now, as the conical clutch engages the gears G3 or G4, it rotates with either of them at a time, which is made possible by the firm grip of the clutch on the inner walls of the gears by friction. The conical clutch is lined with a composite material of high friction coefficient with respect to the gear material (molded asbestos on steel or cast iron). The rotation of the clutch then causes the hollow shaft to rotate [they are both connected by another key] upon which gear G5 is tightly mounted. This consequently, causes it to rotate and transmit its motion to the idler gear assembly, which in turn transmits its motion to the outer system consisting of gears G9 and G10 — which are both rotating independently on bearings.

A selector mechanism connected to the jaw-clutch and controlled by the operator via cables connected to the handle of the roller compactor, then causes the jaw clutch to engage either of gears G9 or G10 one at a time. This engagement further causes a shaft connected to the jaw clutch by means of a lock-jaw engagement [which can also slide over it] to rotate. The sprocket which is connected to this shaft positioned outside the gearbox then rotates and transmits its motion to the rollers.; which then makes the roller compactor to move.

Table 5: Major Components of sub-Assemblies and Main Functions

\begin{tabular}{|c|c|c|c|}
\hline S/No. & SUB-ASSEMBLY & MAJOR COMPONENTS & $\begin{array}{c}\text { SUMMARY OF } \\
\text { MAIN FUNCTION(S) }\end{array}$ \\
\hline 1 & Conical clutch assembly & $\begin{array}{c}\text { Gears G3 and G5, } \\
\text { Conical clutch, and } \\
\text { Systemic shaft assembly }\end{array}$ & $\begin{array}{c}\text { Transmits motion from Idler gears } \\
\text { through gear G5 }\end{array}$ \\
\hline 2 & Output system assembly & $\begin{array}{c}\text { Gears G9 and G10, } \\
\text { Jaw clutch, and } \\
\text { Shaft \& selector mechanism }\end{array}$ & $\begin{array}{l}\text { Transmits translational motion to } \\
\text { the Roller compactor via a Sprocket } \\
\text { and Chain combination outside the } \\
\text { gearbox }\end{array}$ \\
\hline 3 & Systematic shaft assembly & $\begin{array}{c}\text { Hollow shaft, } \\
\text { Solid shaft, } \\
\text { Keys, and } \\
\text { Speed screw mechanism } \\
\end{array}$ & $\begin{array}{l}\text { Engages and dis-engages the Conical } \\
\text { clutch from gears G3 and G4 }\end{array}$ \\
\hline 4 & Idler gears assembly & Gears G6, G7 and G8 & $\begin{array}{l}\text { Transmits motion from Conical } \\
\text { clutch assembly to gear selector } \\
\text { assembly }\end{array}$ \\
\hline
\end{tabular}

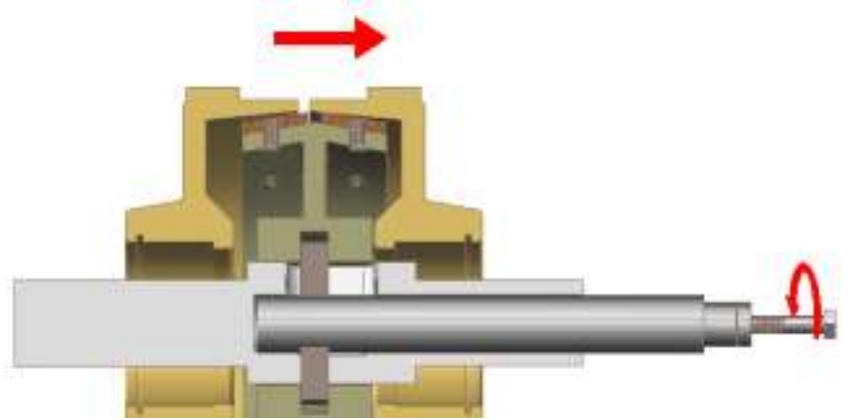

Fig 6: Section through conical clutch assembly during clutch engagement 


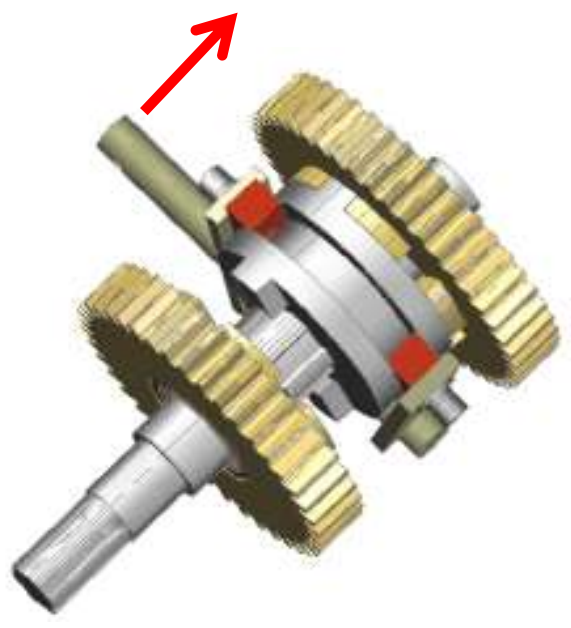

Figure 7: Jaw clutch engaging gear G10 Source: Authors

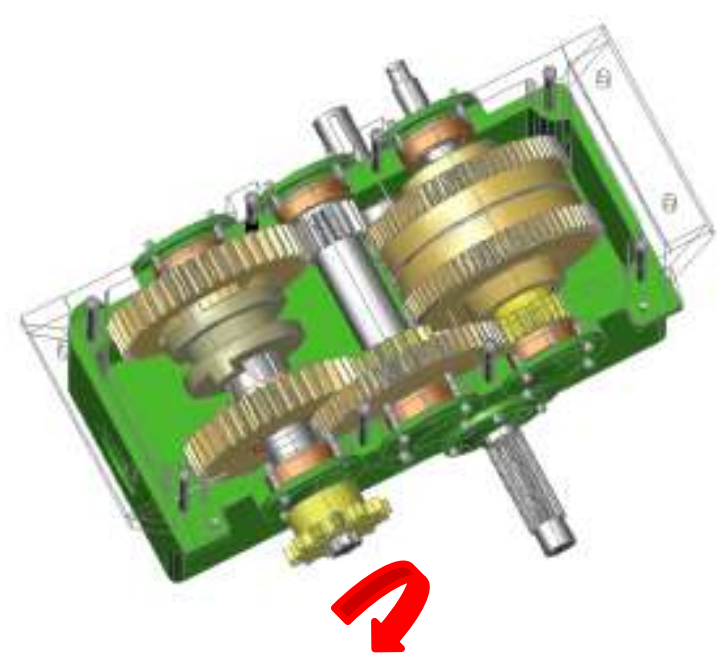

Figure 8: Sprocket rotates to move roller compactor Source: Authors

\subsection{Calculation of Speed of the Engine}

Note that:

and from equation 6 :

$$
1.25 \mathrm{~km} / \mathrm{hr}=\frac{10}{36} \times 2.5 \mathrm{~m} / \mathrm{s}=0.347 \mathrm{~m} / \mathrm{s} \text {. }
$$

where:

$$
\omega_{R}=\frac{v}{r}
$$

$$
v=0.347 \mathrm{~m} / \mathrm{s} \text {, }
$$

Since the diameter of the roller is $500 \mathrm{~mm}=0.5 \mathrm{~m}$; hence the radius $(r)=\frac{0.5}{2}=0.25 \mathrm{~m}$

$$
\therefore \omega_{R}=\frac{0.347}{0.25}=1.39 \mathrm{rad} / \mathrm{s} \text {. }
$$

Thus, this will therefore be taken as the angular speed of the sprocket attached to the roller (driven or gear sprocket).

Now, comparing this with that of the sprocket attached to the output gears shaft (driving or pinion sprocket), we have that:

$$
n_{R}=65 \text {, and } n_{s}=13 \text {. }
$$

Thus:

$$
\begin{aligned}
& \frac{\omega_{s}}{1.39}=\frac{65}{13} \\
& \omega_{s}=\frac{65}{13} \times 1.39=6.95 \mathrm{rad} / \mathrm{s}
\end{aligned}
$$

Consequently, $6.95 \mathrm{rad} / \mathrm{s}$ is the angular speed of the pinion sprocket and also the shaft it is attached to.

Re-writing equation 7 in terms of the gear/pinion arrangement in the gear box:

$$
\frac{\omega_{9}}{\omega_{7}}=\frac{z_{7}}{z_{9}}
$$

where the subscripts represent the gear designations.

Thus, the Angular speed obtained above is that of the gear designated 'G9' i.e. $\omega_{9}=6.95 \mathrm{rad} / \mathrm{s}$

$$
\therefore \omega_{7}=\frac{z_{9}}{z_{7}} \times \omega_{9}=\frac{41}{18} \times 6.95=15.83 \mathrm{rad} / \mathrm{s}
$$

Now, working-up step-wise all the way to the engine:

$$
\begin{aligned}
& \frac{\omega_{5}}{\omega_{6}}=\frac{n_{6}}{n_{5}} \\
& \omega_{6}=\omega_{7} \text { since they are both attached to the same shaft, } \\
& \therefore \omega_{5}=\frac{n_{6}}{n_{5}} \times \omega_{6}=\frac{64}{21} \times 15.83=48.25 \mathrm{rad} / \mathrm{s} \\
& \omega_{5}=\omega_{3} \text { (Assuming no slippage when the conical clutch engages gear } 3 \text { ) } \\
& \frac{\omega_{1}}{\omega_{3}}=\frac{n_{3}}{n_{1}} \\
& \therefore \omega_{1}=\frac{n_{3}}{n_{1}} \times \omega_{3}=\frac{72}{15} \times 48.25=\mathbf{2 3 1 . 5 8} \mathbf{~ r a d} / \mathbf{s}=\mathbf{2 2 1 1} \mathbf{~ \mathbf { p m }}
\end{aligned}
$$

This is therefore, the speed of the engine, since gear G1 is actually a shaft onto which teeth are machined and is connected to the engine without an intermediary gear. 


\subsection{Calculation of Gearbox Ratio}

Considering the Forward higher speed, the gearbox ratio is:

$$
\gamma=\frac{\omega_{1}}{\omega_{9}}=231.58 / 6.95=33.3
$$

\subsection{Calculation of Torque}

Form the model of the conical clutch shown in Figure 4:

$$
\begin{aligned}
& D=147.6 \mathrm{~mm}=0.148 \mathrm{~m} \\
& d=140 \mathrm{~mm}=0.14 \mathrm{~m},
\end{aligned}
$$

From Table 6 in the Appendix 1; for molded asbestos on steel or cast iron in dry condition, while taking the average between the given limits of values; $P_{a}=100 \mathrm{psi}=689476 \mathrm{~N} / \mathrm{m}^{2}$ and $f=0.35$

$$
\therefore F=\frac{\pi \times 689476 \times 0.14}{2}(0.148-0.14)=1213 \mathrm{~N}
$$

and

$$
T=\frac{1213 \times 0.35}{4 \times \sin 11^{\circ}}(0.148+0.14)=\mathbf{1 6 0 . 2} \mathbf{~ N m}
$$

It should be noted that, this value of torque was obtained directly from the physical dimensions of the clutch. These dimensions are not the ones obtained from the 'forward engineering 'design calculations. The usual practice is to increase the dimensions above the designed value when selecting the clutch. In order to account for this in reverse engineering, the obtained value of torque was multiplied by a factor less than 1 (or divided by a factor greater than 1) which takes care of the adjusted dimensions (D, d, etc.) and service application. Table 7 in the Appendix 1 shows safety factor for clutches;

Hence, it was safe to say;

$$
T=\frac{160.2}{2.2}=\mathbf{7 2 . 8 2} \mathrm{Nm}
$$

The above value was taken as the torque transmitted from the engine assuming no loss from the coupling.

\subsection{Calculation of Power of the Engine for the Gearbox}

Finally,

From (10), the Engine power for the gearbox was obtained as follows:

$$
\mathrm{P}=72.82 \times 231.58=16863.66=16.9 \mathrm{KW}=\mathbf{2 3} \mathbf{~ H P}
$$

\subsection{Comparison and Accuracy check/evaluation of Results}

In order to be certain that the design procedure is acceptable, it is necessary to compare the result with existing standards or models. Here, the energy required for adequate compaction of soil was used as the yardstick for the comparison.

Now, according to the modified standard test: AS 1289-E2.1, equipment for road construction works should supply energy within the range of $\mathbf{5 9 5}-\mathbf{2 0 7 2} \mathbf{K J} / \mathbf{m}^{3}$ for adequate compaction [16]; depending on the intent (i.e. whether for road construction, for embankments etc.).

It therefore becomes of interest to us, to check with the dimensions of the components of the roller compactor and with the values of parameters obtained for the engine; if the energy supplied will be within the above-mentioned range.

Now, for dimensional consistency;

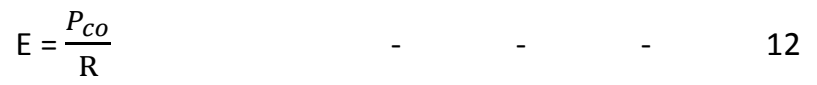

$$
\begin{aligned}
& R=\frac{W \times S \times L \times \varepsilon}{N} \quad-\quad \ldots \quad-\quad \ldots \quad 13[17]
\end{aligned}
$$

\subsection{Useful Power}

To obtain the useful power for operation, consideration was made of the losses encountered from the engine to the rollers. These losses are:

- Losses from the bearings

- Losses from the mating actions of gears

- Losses from the engaging and dis-engaging of the clutch from the forward and reverse reduction gears

- Losses from the chain-sprocket interaction, connecting the gear box to the rollers. 
Also, the following points should be noted:

- Based on the assembly of the proposed gear box, there are six pairs of bearings.

- The coefficient of useful work of a pair of bearings is 0.99 [18].

- Also, there are four pairs of mating gears.

- The coefficient of useful work for a pair of cylindrical spur gear is 0.97 [18].

- Based on practical applications, the average efficiency factor of friction cone clutches during operations at nominal speed is 0.55 (this includes engaging and dis-engaging)

Now, the service factor for chain drives for different applications is shown in Table 8

The reciprocal of the service factor circled in the table will be used since we are accounting for losses

$$
\therefore P_{c o}=18306.399 \times 0.99^{6} \times 0.97^{4} \times 0.55 \times 1 / 1.7=\mathbf{4 5 4 7 . 4 W}
$$

\subsection{Testing the proposed Reverse-Engineered Gearbox for Compaction of different Soil-types}

Knowing the useful power, the rate of production was considered. This is different for various soil types since the 'Compacted lift thickness' and 'Number of passes' required for adequate compaction are different for different soil types.

Now the roller width is $0.68 \mathrm{~m}$, the average compactor speed is $0.347 \mathrm{~m} / \mathrm{s}(1.25 \mathrm{~km} / \mathrm{hr})$ and the average efficiency factor during operation is $50 \mathrm{mins} / \mathrm{hr}$ (0.83) [17]. Values of 'Compacted lift thickness' and 'Number of passes' for similar equipment is shown in Table 9 in the Appendix 1.

3.8.1 For well-graded gravel:

$$
\begin{aligned}
& \mathrm{L}=8 \text { inches }=0.2 \mathrm{~m} \\
& \mathrm{~N}=8 \\
& \mathrm{R}=\frac{0.68 \times 0.347 \times 0.2 \times 0.83}{8}=0.0049 \mathrm{~m}^{3} / \mathrm{s} \\
& \therefore \mathrm{E}=\frac{4547.4}{0.0049}=928 \mathrm{KJ} / \mathrm{m}^{3}
\end{aligned}
$$

3.8.2 For clayey gravel (GC):

$$
\begin{aligned}
& \mathrm{L}=9 \text { inches }=0.23 \mathrm{~m} \\
& \mathrm{~N}=9 \\
& \mathrm{R}=\frac{0.68 \times 0.347 \times 0.23 \times 0.83}{9}=0.005 \mathrm{~m}^{3} / \mathrm{s} \\
& \therefore \mathrm{E}=\frac{4547.4}{0.005}=909.5 \mathrm{KJ} / \mathrm{m}^{3}
\end{aligned}
$$

3.8.3 For silty sands (SM):

$$
\begin{aligned}
& \mathrm{L}=6 \text { inches }=0.152 \mathrm{~m} \\
& N=6 \\
& R=\frac{0.68 \times 0.347 \times 0.152 \times 0.83}{6}=0.00496 \mathrm{~m}^{3} / \mathrm{s} \\
& \therefore E=\frac{4547.4}{0.00496}=916.8 \mathrm{KJ} / \mathrm{m}^{3}
\end{aligned}
$$

3.8.4 For low plastic clay (CL):

$$
\begin{aligned}
& \mathrm{L}=6 \text { inches }=0.152 \mathrm{~m} \\
& \mathrm{~N}=10 \\
& \mathrm{R}=\frac{0.68 \times 0.347 \times 0.152 \times 0.83}{10}=0.003 \mathrm{~m}^{3} / \mathrm{s} \\
& \therefore \mathrm{E}=\frac{4547.4}{0.003}=\mathbf{1 5 1 5 . 8} \mathbf{K J} / \mathrm{m}^{\mathbf{3}}
\end{aligned}
$$

It is pertinent to note that, all of these values for different soil types fall within the acceptable (required) range according to the modified standard test: AS 1289-E2.1 [19-20]. 


\section{CONCLUSION}

The gear box is a two-speed parallel shaft type with a gear box ratio of 33.3 based on the forward direction and consists of 10 spur gears enclosed in a box. One of the gears is a shaft upon which teeth are machined and serves as the input gear, three are idler gears and two are output gears. Two others are in the input system enclosing a conical clutch that transmits torque. One transmits motion to the idler gear system and the remaining is the reduction input gear. In its operation, the conical clutch transmits torque and motion by friction with the inner surfaces of the forward and reverse reductions gears one at a time. The motion is then finally transmitted to the two output gears of different speeds. The output speed selection (forward and reverse) is achieved by the jaw clutch through a mechanism outside the gear box which also automatically enables the conical clutch to engage the forward or reverse reduction gears. From the relevant components of the gear box, it was calculated that it will require a $25 \mathrm{hp}$ and $2211 \mathrm{rpm}$ engine to provide the required energy for optimum compaction. Four soil types where examined and using parameters of the roller compactor in formulae; $928 \mathrm{KJ} / \mathrm{m}^{3}$ of energy was required for well graded gravel for an 8 inches compacted lift, $909.5 \mathrm{KJ} / \mathrm{m}^{3} \mathrm{for} 9$ inches compacted lift of clayey gravel, $916.8 \mathrm{KJ} / \mathrm{m}^{3}$ for 6 inches compacted lift of silty sand and $1515.8 \mathrm{KJ} / \mathrm{m}^{3}$ for a $6 \mathrm{inches}$ compacted lift of low plastic clay. These are within the acceptable range of $595-2072 \mathrm{KJ} / \mathrm{m}^{3}$ according to the modified standard test: AS 1289-E2.1 for road construction works; and therefore, the design analysis is acceptable.

\section{APPENDIX 1}

Table 6: Friction Materials for clutches

\begin{tabular}{|c|c|c|c|c|c|c|}
\hline \multirow[b]{2}{*}{ Material } & \multicolumn{2}{|c|}{ Friction Coefficient } & \multicolumn{2}{|c|}{ Mex. Temperahtere } & \multicolumn{2}{|c|}{ Max. Pressure } \\
\hline & Wet & Dry & ${ }^{\circ} \mathbf{F}$ & ${ }^{\circ} \mathrm{C}$ & psi & kPa \\
\hline Cast iron on cast iron & 0.05 & $0.15-0.20$ & 600 & 320 & $150-250$ & $1000-1750$ \\
\hline Powdered metal ${ }^{*}$ on cast iron & $0.05-0.1$ & $0.1-0.4$ & 1000 & 540 & 150 & 1000 \\
\hline $\begin{array}{l}\text { Powdered metal* on hard } \\
\text { steel }\end{array}$ & $0.05-0.1$ & $0.1-0.3$ & 1000 & 540 & 300 & 2100 \\
\hline Wood on steel or cast iron & 0.16 & $0.2-0.35$ & 300 & 150 & $60-90$ & $400-620$ \\
\hline Leather on steel or cast iron & 0.12 & $0.3-0.5$ & 200 & 100 & $10-40$ & $70-280$ \\
\hline Cork on steel or cast iron & $0.15-0.25$ & $0.3-0.5$ & 200 & 100 & $8-14$ & $50-100$ \\
\hline Felt on steel or cast iron & 0.18 & 0.22 & 280 & 140 & $5-10$ & $35-70$ \\
\hline $\begin{array}{l}\text { Woven asbestos* on steel or } \\
\text { cast iron }\end{array}$ & $0.1-0.2$ & $0.3-0.6$ & $350-500$ & $175-260$ & $50-100$ & $350-700$ \\
\hline $\begin{array}{l}\text { Molded asbestos* on steel } \\
\text { or cast iron }\end{array}$ & $0.08-0.12$ & $0.2-0.5$ & 500 & 260 & $50-150$ & $350-1000$ \\
\hline $\begin{array}{l}\text { Impregnated asbestos* on } \\
\text { steel or cast iron }\end{array}$ & 0.12 & 0.32 & $500-750$ & $260-400$ & 150 & 1000 \\
\hline Carbon graphite on steel & $0.05-0.1$ & 0.25 & $700-1000$ & $370-540$ & 300 & 2100 \\
\hline
\end{tabular}

Source: [15] (page 841)

Table 7: Suggested safety factor table for clutches

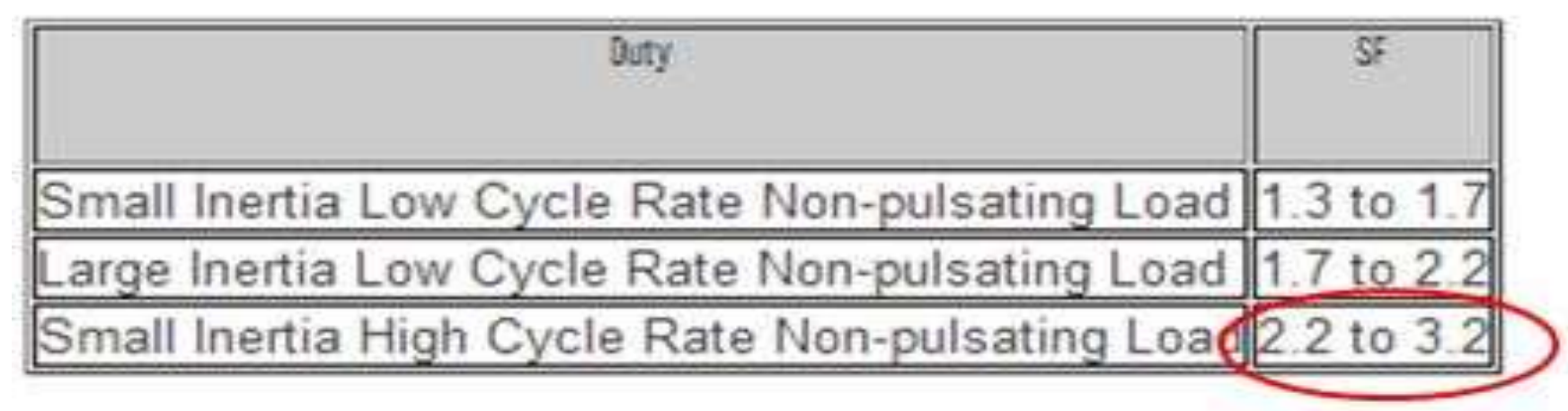


International Journal of Engineering Research And Advanced Technology, Vol.6 (10), October-2020

Source: [21]

Table 8: Chain drive Service factor

\begin{tabular}{|c|c|c|c|c|}
\hline \multirow{3}{*}{ Type of inpact } & \multirow{3}{*}{ Machines } & \multicolumn{3}{|c|}{ Source of Pomer } \\
\hline & & \multirow{2}{*}{$\begin{array}{l}\text { Electric } \\
\text { Notor of } \\
\text { Tubine }\end{array}$} & \multicolumn{2}{|c|}{ humal combyntion Engine } \\
\hline & & & $\begin{array}{l}\text { Wish hydrautic } \\
\text { dive }\end{array}$ & $\begin{array}{c}\text { Whioun hydracilis } \\
\text { dive }\end{array}$ \\
\hline Smooth & $\begin{array}{l}\text { Bet conveyors with small lood fluctuation, chain conveyors, } \\
\text { contrifugal blowers, general textle machinos, machines with } \\
\text { amall bad fluctuation }\end{array}$ & 1.0 & 1.0 & 1.2 \\
\hline Some impact & $\begin{array}{l}\text { Centifugal compressors, marhe engines, conveyors with some load } \\
\text { fluctuation, automatic fumacis, dryers, pliverizers, general machino } \\
\text { lools, compressors, general work machines, general paper mills }\end{array}$ & 1.3 & 1.2 & 1.4 \\
\hline Large impact & 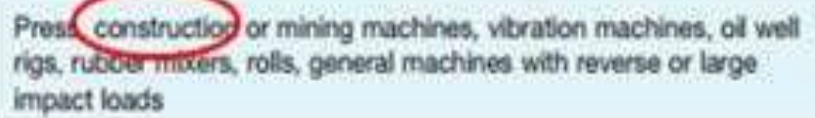 & 1.5 & 1.4 & \\
\hline
\end{tabular}

Source: [22]

Table: 9: 'Compacted lift thickness' and 'Number of passes' for different Soil-types

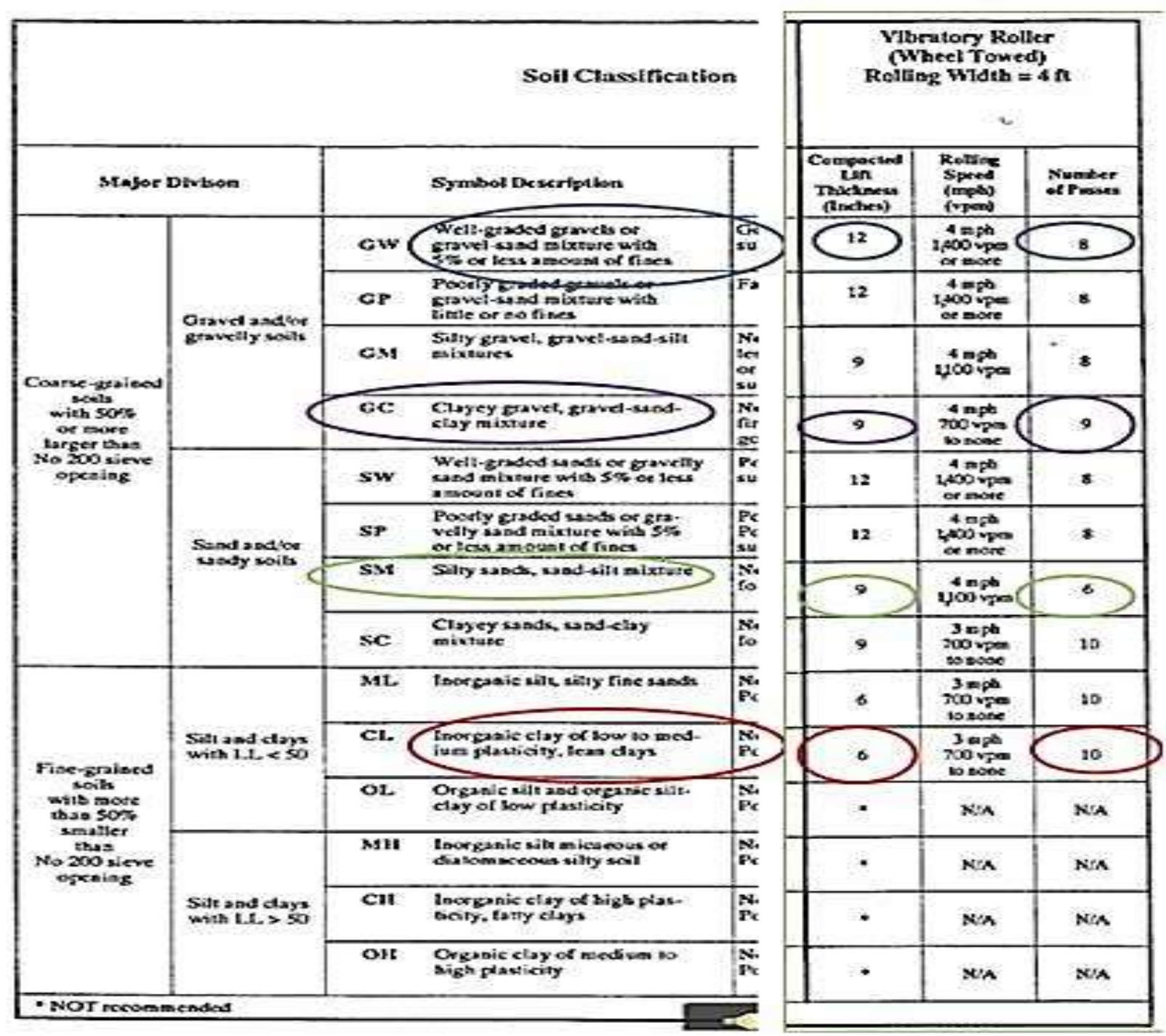

Source: [23] 


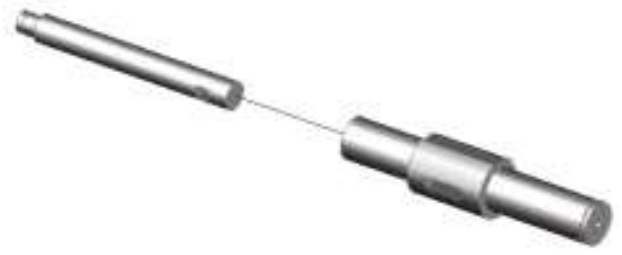

Figure 9: Systematic shaft exploded view (without keys) Source: Authors

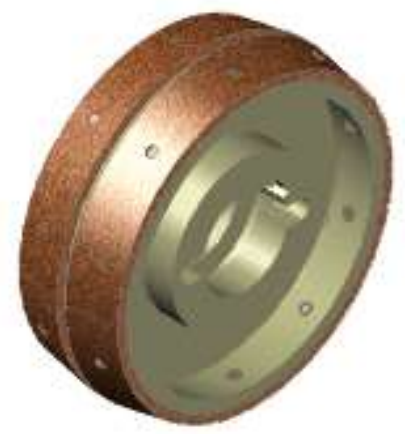

Figure 11: Conical Clutch (With friction lining) view

Source: Authors

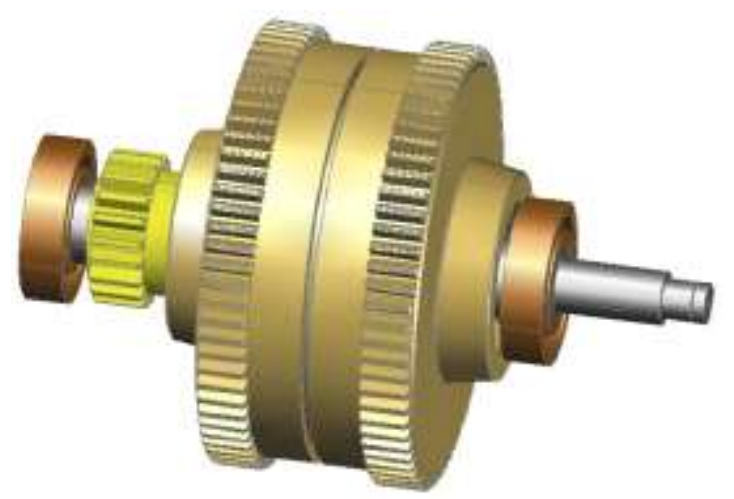

Figure 13: Conical clutch assembly Source: Authors

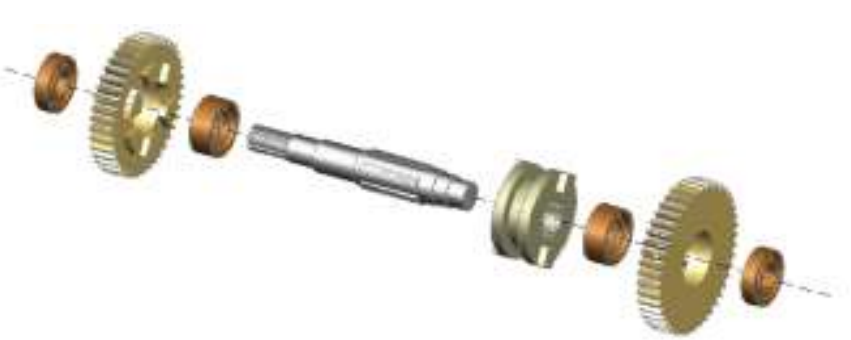

Figure 15: Output system exploded view mechanism)

Source: Authors

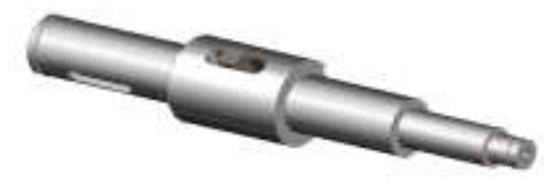

Figure 10: Systematic shaft assembly (keys) Source: Authors

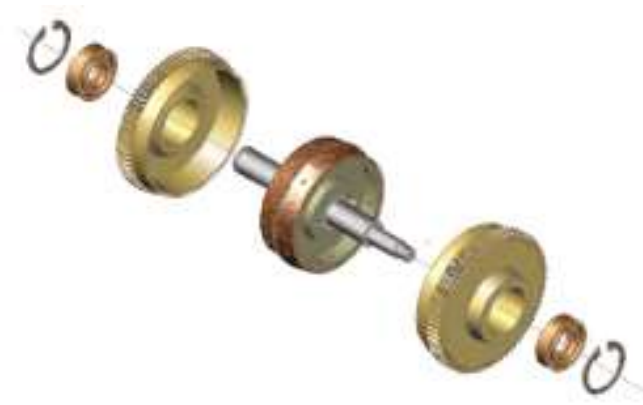

Figure 12: Conical clutch assembly exploded Source: Authors

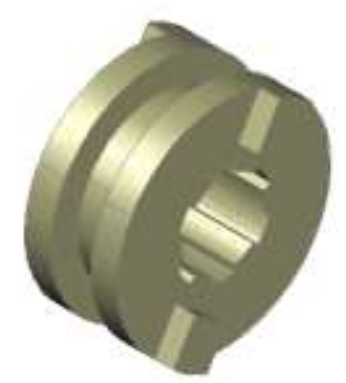

Figure 14: Jaw clutch Source: Authors

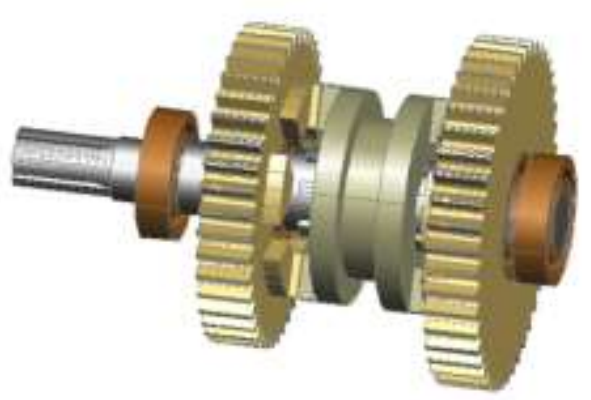

Figure 16: Output System Assembly (without selector Source: Authors 


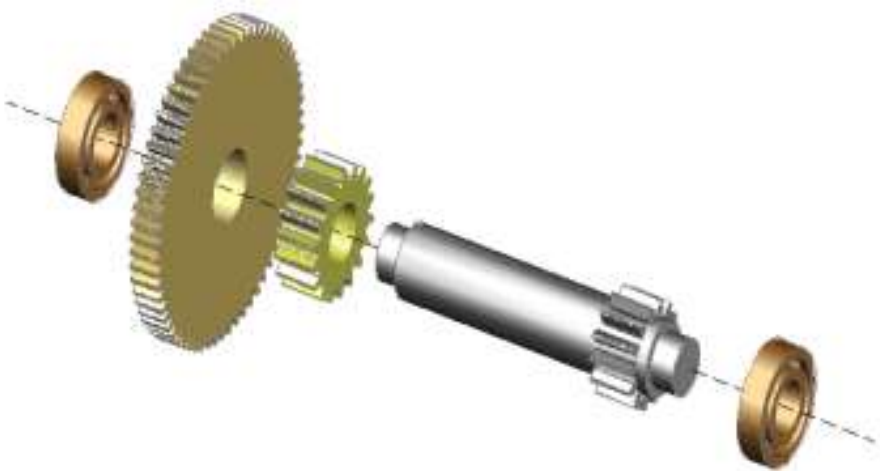

Figure 17: Idler gear system exploded view Source: Authors

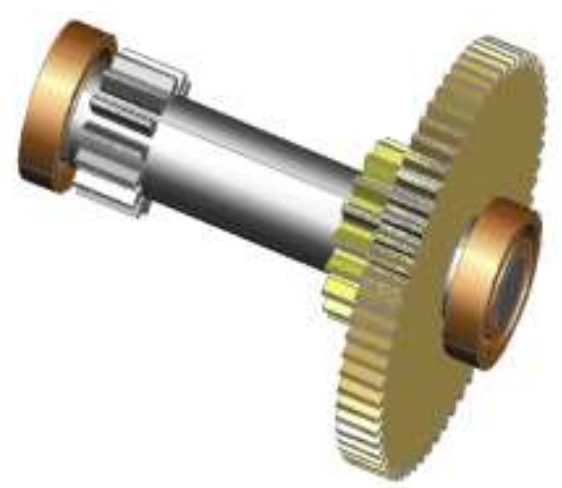

Figure 18: Idler gear system Assembly Source: Authors
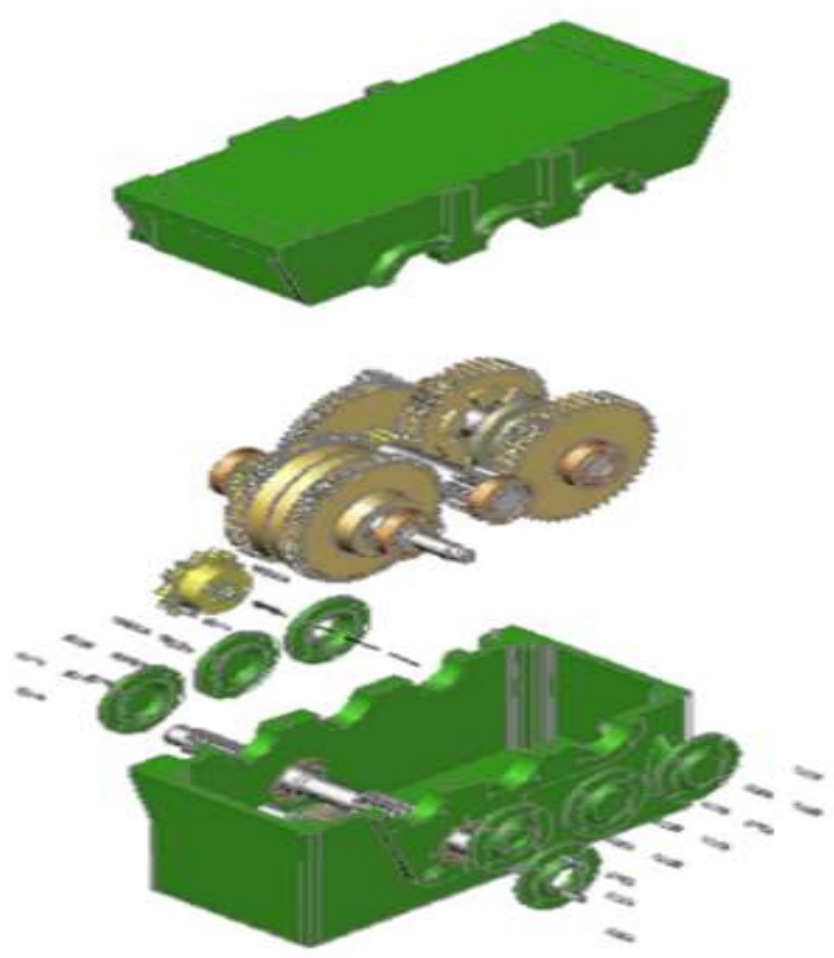

Figure 19: Gearbox Whole Assembly Exploded View Source: Authors 
International Journal of Engineering Research And Advanced Technology, Vol.6 (10), October-2020

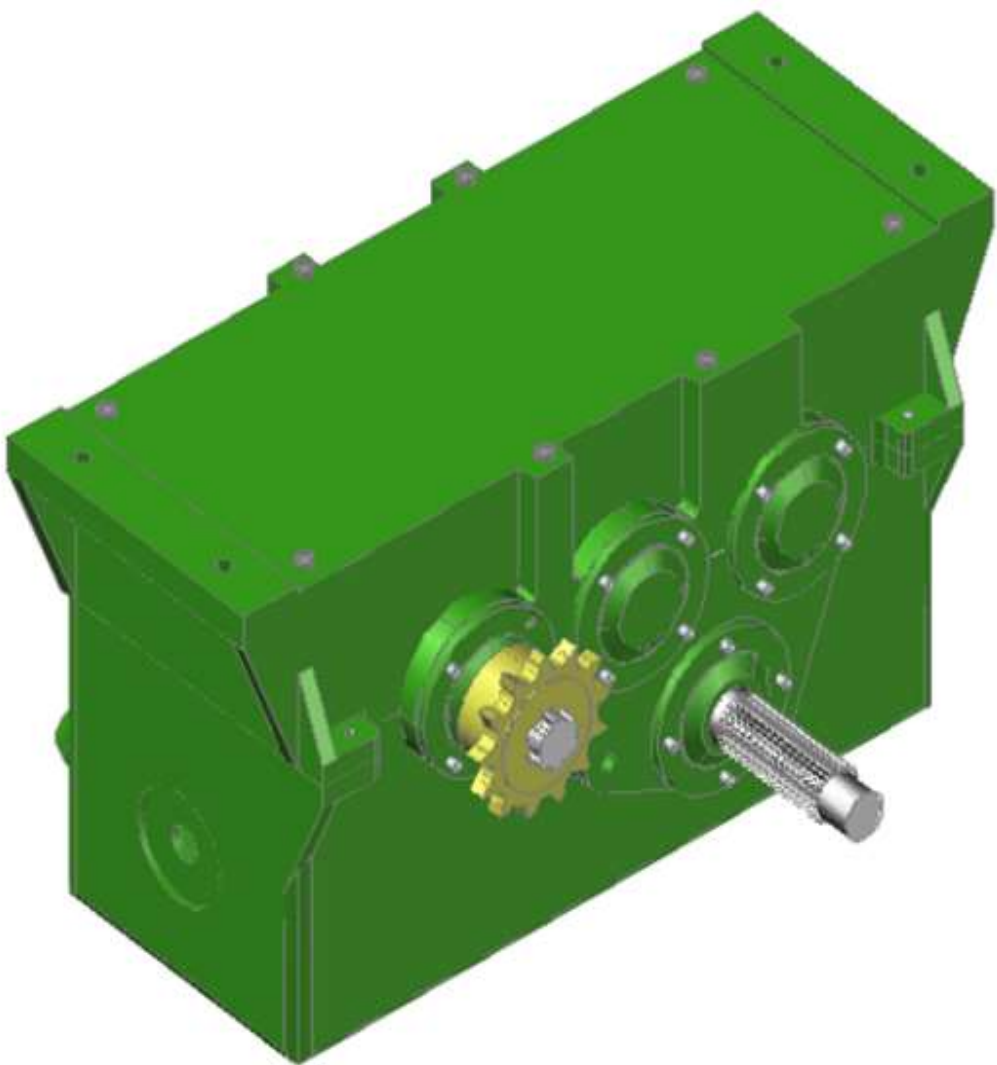

Figure 20: Gearbox Whole Assembly

Source: Authors

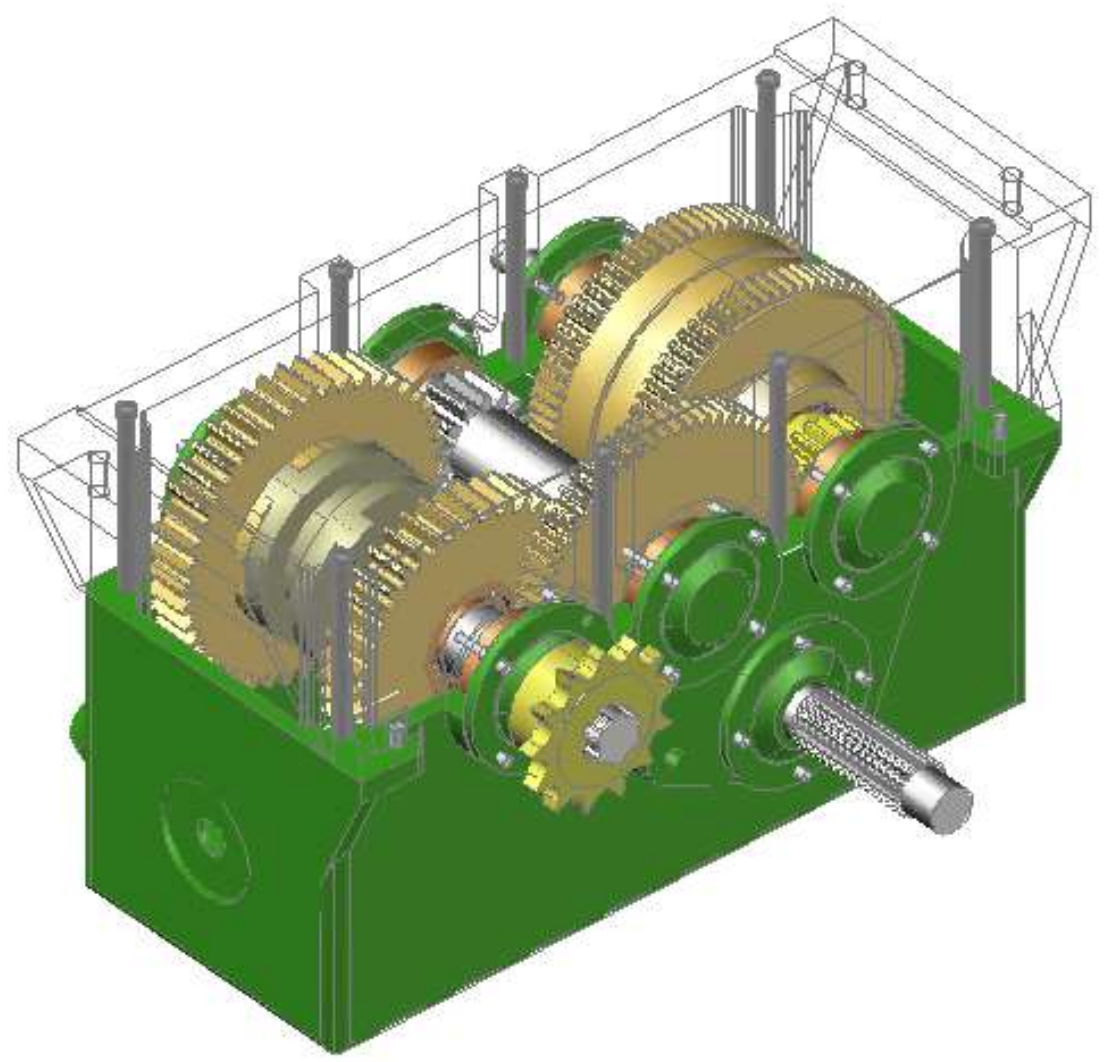

Figure 21: Gearbox Whole Assembly (Showing the internal details)

Source: Authors 


\section{ACKNOWLEDGMENTS}

The authors are truly grateful to GOD almighty for his infinite grace, mercy and favour all through the course of this novel engineering research feat. Also, our sincere appreciation goes to everyone who contributed in one way or the other to the success of this research project. Furthermore, for your inestimable support, we the authors humbly wish to say a "big THANK YOU" to the staff and management of the 'Nigerian Building and Road Research Institute (NBRRI)' - an agency under Nigeria's Federal Ministry of Science and Technology, based in Abuja, Nigeria.

\section{REFERENCES}

[1] E. Eilam, Reversing: Secrets of Reverse Engineering, Wiley India Pvt. Limited, 2005, pp.1-624.

[2] N. Patel and T. Gupta, "Methodology for Designing a Gearbox and its Analysis", International Journal of Engineering Research \& Technology, 2016, vol. 5, Issue 1, ISSN: 2278-0181, pp.780-792.

[3] US Army, Department of Defense Handbook, MIL-HDBK-115 (ME), A publication of the Whole Building design Guide [online] https://www.wbdg.org/ccb/ARMYCOE/COEMILHDBK/hdbk115a.pdf (Accessed on 14 ${ }^{\text {th }}$ June 2012).

[4] R. J. Abella, "Reverse Engineering Industrial Application”, Computers \& Industrial Engineering, 1994, vol. 26, Issue 2, pp.381-385.

[5] H. T. Yau, S. Haque, and C. H. Menq, "Reverse Engineering in the Design of Engine Intake and Exhaust", Manufacturing Science and Engineering, 1993, vol. 64, pp.139-148.

[6] MD Design and Automation, Redesign and Reverse Engineering? Precision Engineering Services Expert Publication [online] http://www.mddesignwi.com/services.html\#: :text=Reverse\%20Engineering\%20is\%20the\%20process,or\%20mold s\%20can\%20be\%20reproduced (Accessed on 12 ${ }^{\text {th }}$ June 2012).

[7] V. Raja and K. J. Fernandes, Reverse Engineering: An Industrial Perspective, Springer Series in Advanced Manufacturing, 2008, ISSN 1860-5168.

[8] Patrick M. Cronin, "Did Pakistan Sell Out America”, A special publication of the Cable News Network (CNN), [online] http://edition.cnn.com/2011/OPINION/08/15/cronin.pakistan.china/index.html?hpt=hp_c1 $\underline{\text { (Accessed on } 18^{\text {th }} \text { June }}$ 2012).

[9] J. Linn III, (2016), "Reverse-engineering the business cycle with Petri nets", OECD Journal: Journal of Business Cycle Measurement and Analysis, vol. 2015/2, [online] https://doi.org/10.1787/jbcma-2015-5jlz9hhp8fns.

[10] J. Kaith, Benefits of Reverse Engineering, An online publication on Computer-Aided Design \& Manufacturing [online] https://groups.google.com/forum/?fromgroups=\#!topic/reverseengineering/boMNW02qP9Q, (Accessed on $18^{\text {th }} \mathrm{June}$ 2012).

[11] D. Yurichev, Reverse Engineering for Beginners, PT Press-China, 2007, pp.1-943

[12] History Lists, Reverse Engineering for War, A Publication of Historical lists from a history fan not a historian, [online] http://historylist.wordpress.com/2008/05/06/reverse-engineering-for-war/, (Accessed on $21^{\text {st }}$ June 2012).

[13] A. C. Telsa, Reverse Engineering: Recent Advances and Applications, Eindhoven University of Technology, Netherlands; IntechOpen, 2012, ISBN: 978-953-51-0158-1, DOI: 10.5772/1850.

[14] J. M. Amiss, F. D. Jones, and H. H. Ryffel, Machinery's Handbook Guide, 27 ${ }^{\text {th }}$ ed., Industrial Press Inc., New York; 2004, ISBN 0-8311-2799-6

[15] R. G. Budynas and J. K. Nisbett, Shigley's Mechanical Engineering Design, $8^{\text {th }}$ ed., McGraw-hill Companies, 2006, ISBN 0-390-76487-6t

[16] Intelligent Construction, Intelligent Compaction, Publication of Transtec Group, Inc-Pavement Engineering Expert [online]http://www.intelligentcompaction.com/downloads/IC_RelatedDocs/SoilCmpct_Fundamentals\%20of\%20Soil\%2 0Compaction.pdf, (Accessed on $3^{\text {rd }}$ May 2014).

[17] Engineers Edge, Gear Design Equations and Formula, A Technical Publication based on the ASME Y14.5-2018. [online] https://www.engineersedge.com/gear formula.htm (Accessed on 1st June 2020).

[18] C. Herrera, and E. Barrios, Machine Design-Gear Box Design, California State Polytechnic University, Pomona, USA; [online] https://portfolium.com/entry/gear-stress-calculation-program (Accessed on 1st June 2020)

[19] D. K. Coder, Soil Compaction Stress and Trees: A Workbook of Symptoms, Measures and Treatments, Published by the Warnell School of Forestry \& Natural Resources, University of Georgia, USA; Publication No. 38, Nov. 2016; [online] https://www.warnell.uga.edu/sites/default/files/publications/WSFNR-16-38\%20Coder.pdf (Accessed on $1^{\text {st }}$ June 2020 ).

[20] D.J. Dunn, Solid Mechanics Tutorial - Gear System, Edexcel Module 21722P HNC/D Mechanical Principles-3 [online] http://www.freestudy.co.uk/dynamics/gears.pdf (Accessed on 16th October 2011).

[21] Logan Clutch Corporation, CH Technical Data for Wet or Dry Operation: Suggested Service Factor Table, a publication of a US-based clutch and brake product manufacturer for customized product design requirements [online] https://loganclutch.com/ch-elements-technical-data-wet-dry (Accessedon 1st June 2020). 
International Journal of Engineering Research And Advanced Technology, Vol.6 (10), October-2020

[22] P. R. N. Childs, Mechanical Design Engineering Handbook, $2^{\text {nd }}$ ed., Butterworth Heinemann, 2019, pp.533-597, DOI: 10.1016/B978-0-08-102367-9.00012-3

[23] US Department of Army Headquarters in Washington, Military Soils Engineering - BITS (C1, FM 5-410), [online] http://www.bits.de/NRANEU/others/amd-us-archive/fm5 410(97).pdf (Accessed on $1^{\text {st }}$ June 2020). 